\title{
HYDROLOGICAL-HYDRAULIC ASSESSMENT OF PROPOSED FLOOD PROTECTION MEASURES
}

\author{
${ }^{1}$ Lea ČUBANOVÁ* ${ }^{2}$ Andrej ŠOLTÉSZ, ${ }^{3}$ Adam JANÍK \\ ${ }^{1,2,3}$ Department of Hydraulic Engineering, Faculty of Civil Engineering, Slovak University of \\ Technology in Bratislava, Radlinského 11, 81005 Bratislava, Slovak Republic \\ e-mail: ${ }^{1}$ lea.cubanova@stuba.sk, ${ }^{2}$ andrej.soltesz@stuba.sk, ${ }^{3}$ adam.janik@stuba.sk
}

Received 29 December 2018; accepted 24 April 2019

\begin{abstract}
Implemented flood protection measures come to a re-evaluation due to changes in the hydrological situation, due to more recently occurring flash floods whose robustness exceeds the capacity of the measures initially proposed. The problem is the structures constructed on the streams as well as the unpermitted house building on the banks, the pollution of the stream or sedimentation. Case study on small catchment with problems of flash floods in the middle Slovakia was solved. Stream channel capacity was not sufficient for higher flow rates; therefore new flood protection measures were proposed (river bed training, low training walls, detention reservoir). Their efficiency was verified via mathematical modeling.
\end{abstract}

Keywords: Design, Detention reservoir, Flood, Hydraulics, Measure, Numerical Model

\section{Introduction}

Since floods are increasingly threatening us, whereas it is more or less unexpected phenomenon, it is necessary to ensure the protection of people and property by appropriate flood protection measures that will meet both environmental and economic considerations. The flash floods (floods from intensive short-term rainfall) in small streams are one of the most significant natural hazards that have negatively hit the whole of Europe in the last 15 years and have caused millions of damage to properties. The flash floods are caused by extreme summer storms in relatively small areas. In the affected catchments, precipitation and gauging stations are often not established.

\footnotetext{
${ }^{*}$ Corresponding Author
} 
Therefore, the genesis of the flash floods is often very difficult and influenced by many uncertainties [1].

Slovak Law Act No. 7/2010 Coll. [2] on flood protection defines the flood as the temporary flooding of a normally un-flooded area due to the effects of natural factors for example precipitation, snow melting, obstacles created by ice jams, various barriers constraining continuous water runoff regardless of whether the obstacles preventing water runoff created in the stream river bed or on the terrain. The flood is a relatively rare phenomenon with extraordinary performance in the runoff process. The genesis of the devastating floods, in addition to the high precipitation, causes many other factors. Besides to the existing orographic, hydrogeological, pedological and vegetation conditions, it is the saturation of the catchment area caused by previous precipitation, accumulated snow, human activity [3].

As defined in Directive 2007/60/ ES, three fundamental criteria are characteristic for the flood [3]:

- the flood has to flooded an area that is not usually covered by water;

- the flood usually causes water to be flooded from the water bodies - from rivers, branches, temporary streams or from the sea;

- flooding due to a failure of a technical facility may or may not be considered as a flood.

For the conditions in Slovakia there are three basic ways through which the floods are flooding the territory [3]:

1. surface runoff caused by precipitation, intensive snow melting and combinations of each other;

2. overflowing of the river bed banks (discharge increasing above the flow capacity of the river bed, by obstruction occurrence in the stream river bed even at a relatively low discharge);

3. by groundwater coming up above the terrain.

Basic causes of the flood formation are [2]:

- sudden or intense rainfall, these floods are called flash floods;

- long-time rainfall, often several (2-5) days, whereas it is possible that similar situation being repeated in a short time. They are mostly associated with the formation of long-term depression, in Slovakia, mainly occurred in summer and autumn;

- snow or ice melting;

- the occurrence of an obstacle in the stream river bed (e.g. ice jams or accumulation of drift wood) and subsequent flooding of the neighboring areas.

\section{Materials and methods}

As there are significant weather changes, the precipitations are non-uniformly distributed within the year as well as within the territory of the Slovak Republic. Therefore, flood situations also occur in areas that previously were not affected by these 
negative hydrological phenomena (flooding of the rural and the urban areas, cellars of the houses, etc.), evident from previous solved projects [4]-[6].

Rainfall intensity and duration limits are not possible to determine exactly because they are dependent on many factors, e.g. type and morphology of landscape, soil water saturation and also they depend on anthropogenic activity (inadequate operation in the landscape). Due to the extremely short time of flood beginning, it is very difficult to alarm inhabitants and for carrying out operative flood protection measures like mobile flood-protection barriers it is mostly too late. That is the reason why it is necessary to prepare appropriate flood-protection measures, which do not need any operation and work automatically.

Based on the analysis of history of the flash floods, it can be stated [1]:

- intensive 3-hour rainfall in a small river basin may cause a catastrophic outflow (by the previous basin saturation with rainfall), which cannot be retained or effectively mitigate by any retention capacity of vegetation cover (forest vegetation) together with the capacity of the shallow soil profile;

- even the perfect river bed training, the extreme load by intensive flush probably does not manage, and therefore it is more effective to protect against the effects of an extreme flood by regulating the construction and development far from the stream, or its alluvial valley in general;

- determination of design values for $\mathrm{N}$-year discharges is never completed, it is constantly necessary to refine these values either by completing the series of new measured flood discharges or using mathematical rainfall-runoff models.

\subsection{Proposal of the flood protection measures}

The procedure of the flood protection measure design (Fig. 1) combines into one complex the technical knowledge, hydraulic calculations and simulations, requirements of the area of interest and spatial potential. It can be stated that each urban area of interest is unique and therefore the design is limited by different boundary conditions (bridges, culverts, house-building very close to the streams, not sufficient place for the creating of the flooding areas, etc.). It is not possible to use standardized schemes of the flood protection, because every design needs an individual approach. In general, there should be kept following procedure, but own proposal will depend on the specific situation:

1. Basic data for model creating - their validity are the most important for the beginning of the preliminary design:

1a) water management data contains information about hydrological situation in the river catchment (daily and annual discharges, precipitations, flood wave, its peak, duration and volume);

1b) geomorphologic data represent the terrain data, obtained by the survey and geodetic measurements of the area of interest. From these data should be detected protected area and problematic parts. Based on the analysis of geology it is possible to design a stable cross section of the stream, to choose appropriate profile of the detention reservoir, etc. The designer should make a detailed survey of the stream and its vicinity, to determine 
the cross sections by the geodetic measurements and to find out the discharge and water level in the stream in the same time for achieving the relevant values for the future mathematical model calibration (a review of the depths, longitudinal slopes of the river bed bottom, roughness coefficients and structures on the stream);

2. Mathematical model creation of the present state in order to identify critical parts of the area to be protected by the flood protection measures, thus detecting the flow capacity of the stream that endangers the neighboring area with floods. Therefore, 1- or 2-D mathematical model is building (1-D model is sufficient for the preliminary design), whose credibility is increased by calibration. In practice, it is not often that model is verified, because it is not possible to perform at the same time a water level and discharge measurements during flood situations, because on the small river basins are no gauging stations established;

3. Proposal of the flood protection measures according to the specific situation and conditions. This proposal is then inserted into the mathematical model of the present state where the effects of the proposed measures are found out. On the basis of the analysis of the stage without the designed measures and with them it can be stated their suitability and effectiveness.

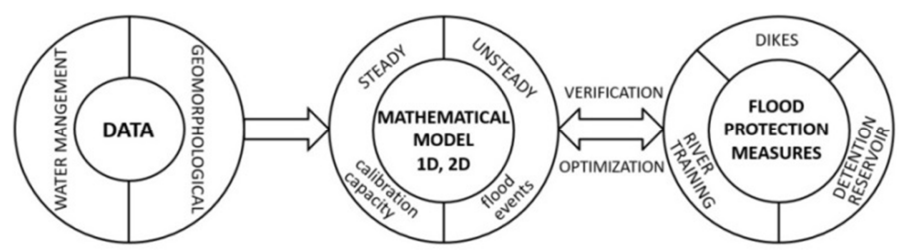

Fig. 1. Procedure of the flood protection measure proposal

\subsection{Description of simulation model}

For the simulation of the solved area was used freeware Hydrologic Engineering Center - River Analysis System (HEC-RAS), which is suitable tool for modeling of the both steady and unsteady flow simulation in the stream, as well as for structure modeling on the stream. HEC-RAS is currently capable of performing $1 \mathrm{D}$ water surface profile calculations for steady gradually varied flow in natural or modified channels. Subcritical, supercritical and mixed flow regime water surface profiles can be calculated. Water surface profiles are computed from one cross section to the next by solving the energy Eq. (1) with an iterative procedure called the standard step method [7]:

$$
Z_{2}+Y_{2}+\frac{a_{2} v_{2}^{2}}{2 g}=Z_{1}+Y_{1}+\frac{a_{1} v_{1}^{2}}{2 g}+h_{e},
$$

where $Z_{1}, Z_{2}$ are the elevations of the main channel inverts (m); $Y_{1}, Y_{2}$ are the depths of water at cross sections $(\mathrm{m}) ; v_{1}, v_{2}$ are the average velocities $\left(\mathrm{m} . \mathrm{s}^{-1}\right) ; \alpha_{1}, \alpha_{2}$ are the 
velocity weighting coefficients (-); $g$ is the acceleration due to gravity $\left(\mathrm{m} \cdot \mathrm{s}^{-2}\right) ; h_{e}$ is the energy head loss (m),

$$
\left(h_{e}=L \overline{S_{f}}+C\left|\frac{a_{2} v_{2}^{2}}{2 g}-\frac{a_{1} v_{1}^{2}}{2 g}\right|\right) ;
$$

and $L$ is the discharge weighted reach length (m),

$$
\left(L=\frac{L_{l o b} \bar{Q}_{l o b}+L_{c h} \bar{Q}_{c h}+L_{r o b} \bar{Q}_{r o b}}{\bar{Q}_{l o b}+\bar{Q}_{c h}+\bar{Q}_{r o b}}\right) ;
$$

$\overline{S_{f}}$ is the representative friction slope between two sections (weighted average value derived either directly from the friction slopes at each cross section or directly from a weighted average value of the channel conveyances) (-); $C$ is the expansion or contraction loss coefficient (-); $L_{l o b}, L_{c h}, L_{r o b}$ are the cross section reach lengths specified for flow in the left overbank, main channel, and right bank, respectively (m); $\bar{Q}_{l o b}+\bar{Q}_{c h}+\bar{Q}_{r o b}$ are the arithmetic average of the flows between sections for the left overbank, main channel, and right over-bank, respectively $\left(\mathrm{m}^{3} \cdot \mathrm{s}^{-1}\right)$.

Unsteady flow routing - the physical laws, which govern the flow of water in a stream are the principle of conservation of mass (continuity), and the principle of conservation of momentum. These laws are expressed mathematically in the form of partial differential equations, which will hereafter be referred to as the continuity and momentum equations. Final form of the continuity Eq. (2) [7]:

$$
\frac{\partial A_{T}}{\partial t}+\frac{\partial Q}{\partial x}-q_{1}=0
$$

where $A_{T}$ is the total flow area $\left(\mathrm{m}^{2}\right) ; t$ is the time (s); $Q$ is the flow $(Q(x, t))\left(\mathrm{m}^{3} \cdot \mathrm{s}^{-1}\right) ; x$ is the distance measured along the channel $(\mathrm{m}) ; q_{1}$ is the lateral inflow per unit length $\left(\mathrm{m}^{2} \cdot \mathrm{s}^{-1}\right)$.

Conservation of momentum is expressed by Newton's second law. The final form of the momentum Eq. (3) is:

$$
\frac{\partial Q}{\partial t}+\frac{\partial Q V}{\partial x}+g A\left(\frac{\partial z}{\partial x}+S_{f}\right)=0
$$

where $V$ is the velocity $\left(\mathrm{m} \cdot \mathrm{s}^{-1}\right) ; g$ is the acceleration due to gravity $\left(\mathrm{m} . \mathrm{s}^{-2}\right) ; A$ is the cross sectional area $\left(\mathrm{m}^{2}\right) ; \partial z / \partial x$ is the water surface slope (-); $S_{f}$ is the friction slope (positive for flow in the positive $\mathrm{x}$-direction) (-).

HEC-RAS calculates energy losses caused by structures as bridges and culverts in three parts. One part consists of losses that occur in the reach immediately downstream from the structure, where an expansion of flow generally takes place. The second part is the losses at the structure itself, which can be modeled with several different methods. 
The third part consists of losses that occur in the reach immediately upstream of the structure, where the flow is generally contracting to get through the opening.

Methods for computing the water surface profile through a bridge [7]:

- low flow (water surface is below the maximum low chord of the bridge deck) if the momentum downstream is greater than critical depth momentum inside the bridge, the class of flow is considered to be completely subcritical (i.e. class A low flow: there are four available methods for computing losses through the bridge - energy equation, momentum balance, Yarnell equation, Federal HighWay Administration Water Surface PROfile (FHWA WSPRO) method, if the momentum downstream is less than the momentum at critical depth, in the controlling bridge section, then it is assumed that the constriction will cause the flow to pass through critical depth and a hydraulic jump will occur at some distance downstream (i.e. class B low flow), if the profile is completely supercritical through the bridge, then this is considered class $\mathrm{C}$ low flow;

- high flow - user must choose between either the energy based method or the pressure and flow approach.

The culvert routines in HEC-RAS are similar to the bridge routine. The layout of cross sections (four cross sections are required - one cross section sufficiently downstream from the culvert such that the flow is not affected by the culvert, one at the downstream end of the culvert, one at the upstream end of the culvert, and one cross section located far enough upstream that the culvert again has no effect on the flow), the use of the ineffective areas, the selection of loss coefficients, and most other aspects of bridge analysis apply to culverts as well [7].

\section{Case study}

Procedure of the flood protection measure design described above was applied to the solution of the flood protection in the village Vel'ká Lúka (Central Slovakia, near Zvolen town) through which the Lukavica stream flows (Fig. 2).

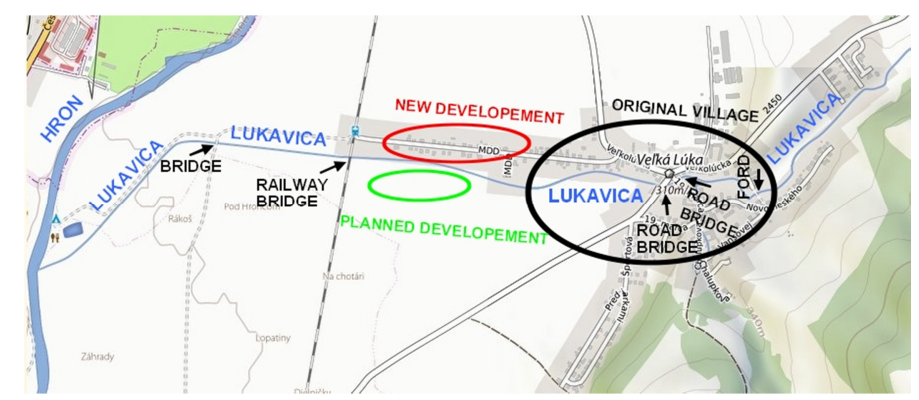

Fig. 2. Area of interest - stream Lukavica, village Vel'ká Lúka, structures on the stream

River bed training has been made in the past in different phases and for different discharge capacities. In the village of Vel'ká Lúka there have been several cases of 
flooding of the surrounding areas through the waters of the Lukavica stream (the higher flood stages occurring in 12/2009, 3/2013 and 2/2016). This problem becomes more serious that in recent years individual houses have been built in the village along the Lukavica stream in direct contact with the floodplain area, and other builders are demanding solutions of the flood situation in the urban area. The task is complicated by the fact that there is no space in the village's urban area to increase the flow capacity of the stream.

The basic accessible data summarized:

- current geodetic measurement of the Lukavica stream (3.5 km long - 38 cross sections);

- measurement of the water level and discharge (unfortunately only by the low water stage), these data are used for the calibration of the mathematical model;

- hydrological data (M-day discharges, N-year discharges, design flood wave);

- geological data from the boreholes.

It followed creation of the steady non-uniform mathematical model of the stream channel to find out the actual capacity of the channel. Into the model all structures were included and model was calibrated on measured water levels and discharge (calibration was done only for low flow, it means calibrated was only main channel and roughness of the banks was estimated according to the reconnaissance). It was identified the capacity of the river bed by value $Q=7 \mathrm{~m}^{3} \cdot \mathrm{s}^{-1}$, whereas $Q_{1}=8 \mathrm{~m}^{3} \cdot \mathrm{s}^{-1}$ (1-year discharge) [8]. Subsequently, Slovak Water Management Enterprise started with sediment dredging (Fig. 3), but only from the river bed in the central part of the village (estimated volume of sediments was $2200 \mathrm{~m}^{3}$ ). Therefore, also cross sections were adjusted and model was modified to give real results. The capacity of the river bed without sediments risen up to the value $Q=15.9 \mathrm{~m}^{3} \cdot \mathrm{s}^{-1}$, whereas $Q_{2}=12 \mathrm{~m}^{3} \cdot \mathrm{s}^{-1}$ [8]. From the simulations of the water level regimes should be concluded that water level regime remained nearly the same like for the previous calculated lower capacity, but river bed capacity redoubled $\left(Q=7-15.9 \mathrm{~m}^{3} \cdot \mathrm{s}^{-1}\right)$ (Fig. 4).
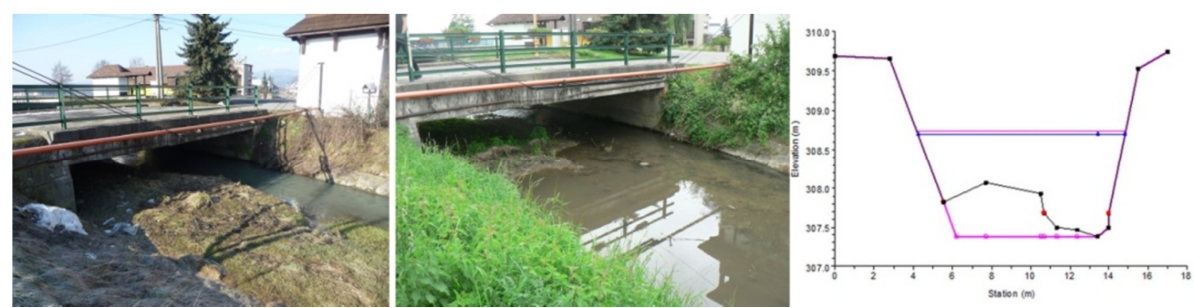

Fig. 3. Sediment dredging - cross section with sediments, without sediments and

their comparison (water level nearly the same, but different capacity of the stream channel) (Photos: Čubanová)

From previous simulations it was absolutely clear that channel capacity is not sufficient neither for $Q_{5}=21 \mathrm{~m}^{3} . \mathrm{s}^{-1}$ [8]. Design flood wave has a peak $Q_{100}=49 \mathrm{~m}^{3} \cdot \mathrm{s}^{-1}$ (100-year discharge)and the flood volume represents $1.8 \mathrm{mil} . \mathrm{m}^{3}$ [8]. The capacity of the river bed is not possible to increase by any measures. The housing development is so 
close to the stream banks that river bed training is unfeasible (widening or deepening of the channel, routing change, disagreement of the railway company to reconstruct the railway bridge, dikes construction has no available area).

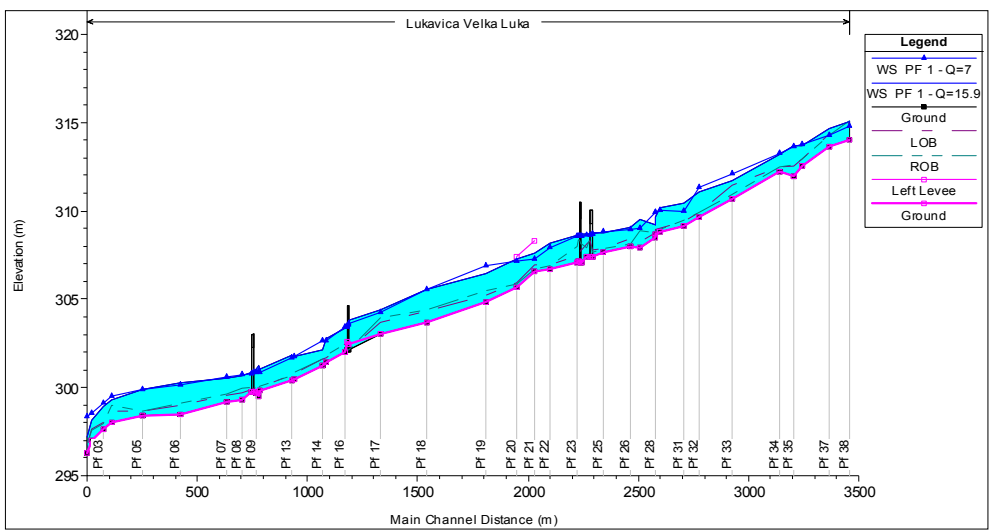

Fig. 4. Graph of the water level regime for the capacity of the river bed with $\left(Q=7 \mathrm{~m}^{3} \cdot \mathrm{s}^{-1}\right)$ and without sediments $\left(Q=15.9 \mathrm{~m}^{3} \cdot \mathrm{s}^{-1}\right)$

Therefore, it followed the idea of the detention reservoir design above the village to retain the huge flood volume and to outflow only the flow equal to the capacity discharge of the stream river bed. Subsequently, geodetic measurements of the area with supposed detention reservoirs were done. The measurement was made from 23 temporarily stabilized auxiliary measurement points, the coordinates of the points were determined in the System of coordinates of the Uniform Trigonometric Cadastral Network of the Slovak Republic using Global Navigational Satellite Systems (GNSS) via the SlovaK Real-time POsitioning Service (SKPOS). The point's elevations of the point field were also determined by the use of SKPOS in the elevation system Baltic Vertical Datum after adjustment. There were 3451 points surveyed, from which the digital terrain model in the form of a Triangulated Irregular Network (TIN) model was obtained.

It is necessary to note that different variants WERE PROVEN - only 1 big detention reservoir or several smaller reservoirs on the tributaries of the Lukavica stream.

\subsection{Final proposal of the flood protection measures}

For the hydraulic model of the flood wave routing, a detention reservoir was designed in the Lukavica stream valley in rkm 3.366 (approx. $530 \mathrm{~m}$ above the village), whereas the dam of the detention reservoir is designed up to the line of the geodetic surveying (Fig. 5). Proposed dam does not reach the road that leads through the valley between the villages of Lukavica and Vel'ká Lúka.

From the digital terrain model, the storage elevation curve $V=f(H)$ (Table $I)$ was developed for the chosen profile of the detention reservoir and design height of the dam and diameter of the outlet culvert. 


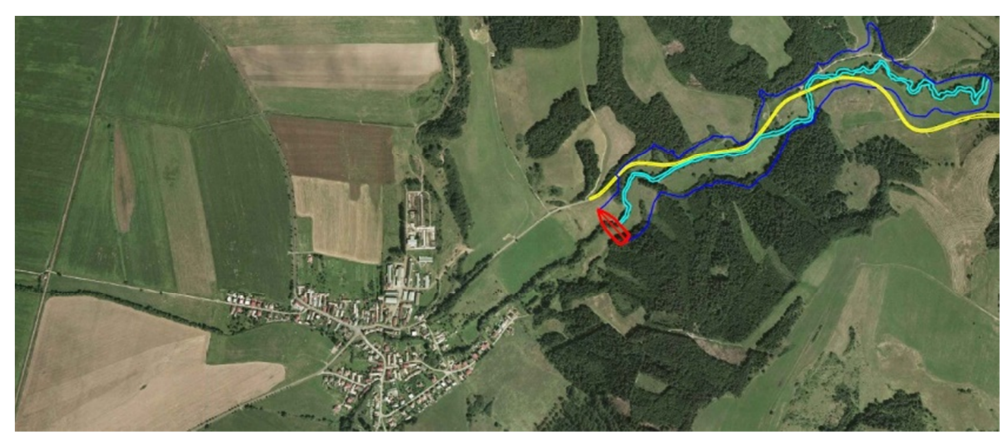

Fig. 5. Location of the detention reservoir dam on the Lukavica stream in rkm 3.366

Table I

The storage elevation curve for the designed detention reservoir on the Lukavica stream

\begin{tabular}{|l|l|l||l|l|l|}
\hline Dam height & H & $\Sigma \mathrm{V}$ & Dam height & H & $\Sigma \mathrm{V}$ \\
\hline$[\mathrm{m}]$ & {$[\mathrm{m}$ a. s. 1.$]$} & {$\left[\mathrm{m}^{3}\right]$} & {$[\mathrm{m}]$} & {$[\mathrm{m}$ a. s. 1.$]$} & {$\left[\mathrm{m}^{3}\right]$} \\
\hline 0 & 314.5 & 0 & 6 & 320.25 & 183511 \\
1 & 315.25 & 3172 & 7 & 321.25 & 264537 \\
2 & 316.25 & 14856 & 8 & 322.25 & 363693 \\
3 & 317.25 & 35915 & 9 & 323.25 & 487167 \\
4 & 318.25 & 68274 & 10 & 324.25 & 633291 \\
5 & 319.25 & 116781 & 11.5 & 326.00 & 650000 \\
\hline
\end{tabular}

The design of the bottom outlet was done to not overflow the dam of the detention reservoir by the $Q_{100}$ flood wave or in terms of water level in the reservoir does not reach the level of the spillway. In this case, a circular opening with a diameter of $1.5 \mathrm{~m}$ was designed and simulated as a culvert in the HEC-RAS model for unsteady state of the flood wave routing (flattening). The terrain elevation at site of the damming is 314.5 m. a. s. 1. and the dam crest elevation is $326 \mathrm{~m}$. a. s. 1., the total height of the detention reservoir dam is $11.5 \mathrm{~m}$ and the volume of thus created reservoir is approximately 650 $000 \mathrm{~m}^{3}$ (Fig. 6). This proposal resulted in a flood wave routing (peak discharge of 49 $\mathrm{m}^{3} . \mathrm{s}^{-1}$ ) and outflow discharge from the detention reservoir was of $15.9 \mathrm{~m}^{3} . \mathrm{s}^{-1}$ (Fig. 7). This suggestion has been evaluated in the terms of the increased capacity of the river bed (after dredging) in the village as sufficient.

The dam of the detention reservoir was designed as an earth fill dam with a volume about $25650 \mathrm{~m}^{3}$ at the proposed crest elevation of $326 \mathrm{~m}$ a. $\mathrm{s}$. 1. (for the cross section shown in Fig. 6). The spillway itself, which is also designed to the value of $Q_{100}=49 \mathrm{~m}^{3} \cdot \mathrm{s}^{-1}$, is located in the left-hand side of the dam of the detention reservoir at a sufficient depth under the road. The length of the spillway crest reaches a value up to 50 $\mathrm{m}$ at the overflow head of $0.5 \mathrm{~m}$.

Finally, the whole designed area was joined together to one simulation model of unsteady state (detention reservoir and downstream river bed), which simulated a flood situation in the area of interest. The detention reservoir routed the flood wave and the outflow discharge reached the assumed capacity of the dredged stream channel. 
Therefore, the model has been supplemented with low training walls (dikes) in the centre of the village to achieve the safety by the increased discharges in this part of the village (the most critical place where water is overflowing both banks - towards new and planned development), between profile 17 and 23, it means between the railway bridge and the road bridge of the main road, in order to reach a safety freeboard above the water level at $Q=20 \mathrm{~m}^{3} \cdot \mathrm{s}^{-1}\left(\approx Q_{5}=21 \mathrm{~m}^{3} \cdot \mathrm{s}^{-1}\right)$ [8].
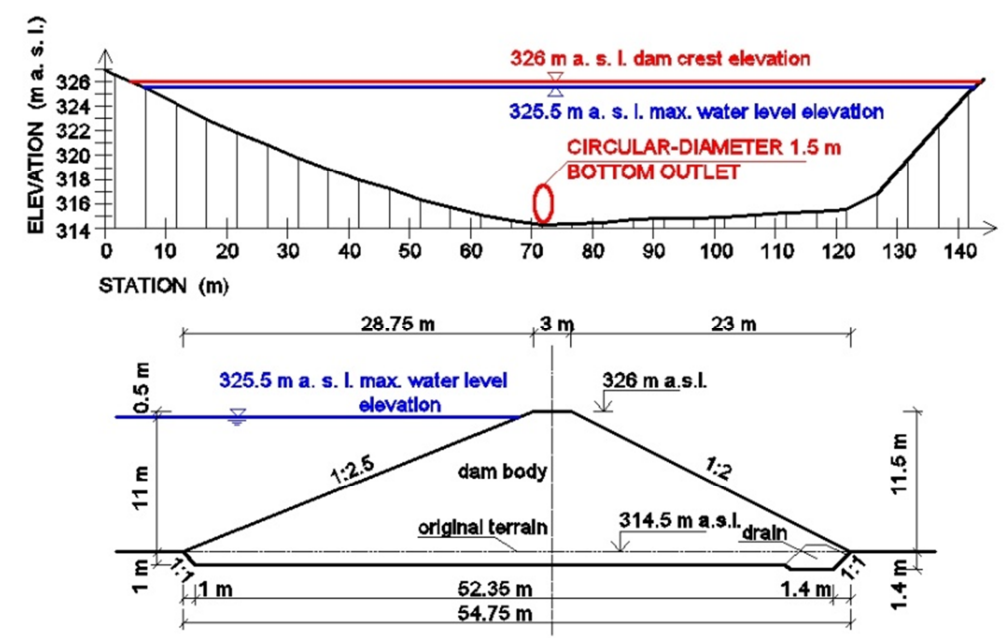

Fig. 6. Cross section of the valley and dam of the proposed detention reservoir at the stream of Lukavica in rkm 3.366

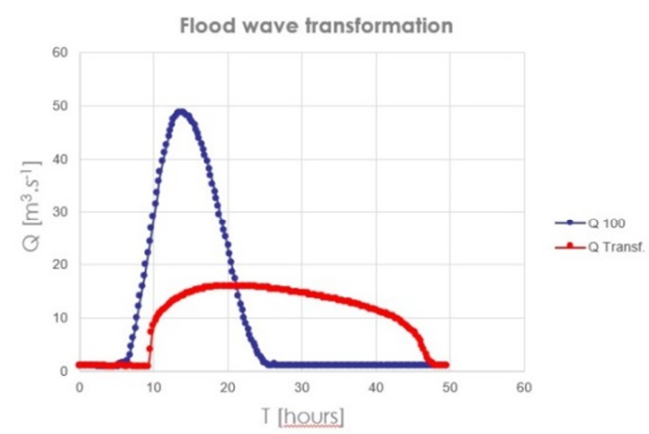

Fig. 7. Graphical illustration of the transformation of the designed flood wave $Q_{100}$ for the dam height $11.5 \mathrm{~m}$ and circular orifice of bottom outlet with the diameter $1.5 \mathrm{~m}$

Elevation of the low dikes in the profile 23 is $309.25 \mathrm{~m}$. a. s. 1 . and in the profile 17 is $305.08 \mathrm{~m}$ a. s. 1., the longitudinal slope is $i_{o}=4.7 \%$ o (Fig. 8). It is representing an increase of the bank line of the river bed in this section from $0.25 \mathrm{~m}$ (profile 17) to $0.45 \mathrm{~m}$ (profile 22), while it must be secured smooth connection of the low dikes to the road bridge (profile 23) as well as to the railway bridge (profile 17). 


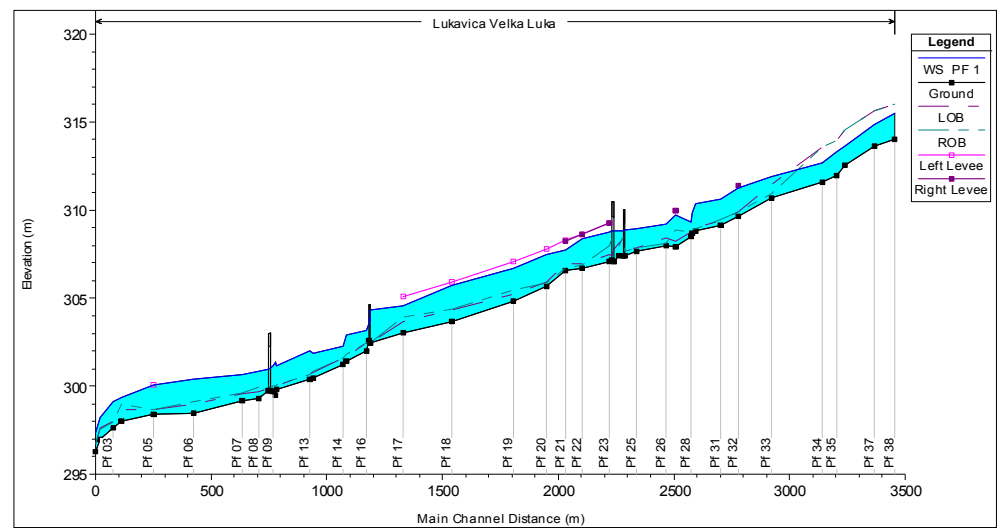

Fig. 8. Graph of the water level regime for $Q=20 \mathrm{~m}^{3} \cdot \mathrm{s}^{-1}$ with low dikes in the central part of the village (PF 17 - PF 23) and with river bed training downstream the dam (PF 34 - PF 38)

Also, it was designed river bed training immediately downstream the dam of the detention reservoir (between profile 34 and profile 38, it means in the rural area above the village of Vel'ká Lúka) because it will be subjected and eroded during flood stages by the outflowing from the reservoir. Proposed cross sections downstream the dam are trapezoidal shaped, with a width in the river bed bottom of $b=4.5 \mathrm{~m}$ and bank slope of $1-1.5$, whereas they must be sufficiently fortified.

It is necessary to note that the ford in the village is preserved; it was no request for its removing. In this place the water will outflow to the road, which is passing this ford. Neighboring houses are higher placed and therefore should not be affected by water.

\section{Conclusion}

The paper presents a hydrological-hydraulic assessment of the flood protection of the village in the middle part of Slovakia. During the common hydrological situations, the stream flows at minimum water level (few centimeters). However, the design flood wave has a huge volume. The stream channel modification is not possible, not even its widening or protection by dikes, so it seems the most appropriate solution to design detention reservoir above the village with a runoff that the river bed is able to transfer it without overflowing in the village.

The introduced proposal process has proved to be the most appropriate in several previously solved cases of the relatively small river basins threatened by the flash floods. Since no precipitation and gauging stations are established there, it is no possibility to alert the population in time. Flood protection measures must be adapted to the existing infrastructure (bridges, culverts, etc.) and often to the dense surrounding development, notably if river bed training or design of dikes or floodplains is not possible. Detention reservoir (or detention reservoir above the village) represents an effective solution of flood protection as well as a water harvesting element in the country. 
In the future, citizens should be instructed in flood protection. Flood protection measures must be included in the municipal plans of the villages, the building permits cannot be issued for construction very close to the stream, it is necessary to avoid stream pollution and flow capacity decreasing by rubbish reducing the flow profile.

Generally, flood protection measure design is never ending story because of extreme weather changes occurring in last few years causing floods of short time duration and huge volume. Water management measure should be design to fulfill both environmental and economic point of view.

\section{Acknowledgements}

The paper was developed within the frame of and based on the financial support of the VEGA 1/0800/17 project 'Optimization of the flood protection of municipalities in river basin of mountain streams' and of the APVV-16-0278 project 'Use of hydromelioration structures for mitigation of the negative extreme hydrological phenomena effects and their impacts on the quality of water bodies in agricultural landscapes'.

\section{References}

[1] Pekárová P., Svoboda A., Miklánek P., Halmová D. Flash floods problems on small streams, Part I. - 7th June, 2011 flood analysis in small Carpathians, Slovakia, Proc. of the Conference River Basin and Flood Risk Management, Častá - Papiernička, Slovakia, 6-8 December 2011, http://www.vuvh.sk/download/ManazmentPovodi_rizik/zbornik Prispevkov/Konferencia/Prispevky/SekciaC/Pekarova_a_koll.pdf, (last visited 29 December 2018).

[2] Act No. $7 / 2010$ Coll. on protection against floods (in Slovak), http://extwprlegs1.fao.org/docs/pdf/slo124718.pdf, (last visited 29 December 2018.

[3] Ministry of Environment of the Slovak Republic. Analysis of the state of flood protection in the territory of the Slovak Republic (Annex 1), (in Slovak) 2011, https://www.minzp.sk/files/sekcia-vod/priloha_1-suhrn_vysledkov_analyzy.pdf, (last visited 29 December 2018).

[4] Pindjaková T., Kelčík S., Šoltész A. Simulation of flood progress on the river Gidra, Pollack Periodica, Vol. 11, No. 1, 2016, pp. 25-34.

[5] Kelčík S., Pindjaková T., Šoltész A. Assessment and design of the flood protection measures in the district of Levice (Slovakia), Pollack Periodica, Vol. 11, No. 1, 2016, pp. 35-41.

[6] Janík A., Šoltész A. Flash flood mitigation modeling - Case study Small Carpathians, Pollack Periodica, Vol. 12, No. 2, 2017, pp. 103-116.

[7] U.S. Army Corps of Engineers (USACE). HEC-RAS River Analysis System, User's manual, version 5.0. Hydrologic Engineering Center, Davis, 2016, http://www.hec.usace. army.mil/, (last visted 29 December 2018).

[8] Šoltész A., Čubanová L., Janík A., Živčicová K. Velká Lúka - flood protection measures in Lukavica river basin, (in Slovak) Slovak University of Technology in Bratislava, Faculty of Civil Engineering, 2018. 